\title{
Modified Gelcasting Process to Prepare Porous Trifasic and Bifasic Hydroxyapatite scaffolds
}

\author{
F. Mendonça ${ }^{1}$ a, L. H. L. Louro ${ }^{1 \text { b }}$, J.B. de $\operatorname{Campos}^{2 c}$, A. M. Rossi ${ }^{2 d}$, \\ M. H. Prado da Silva ${ }^{1}$ \\ ${ }^{1}$ Instituto Militar de Engenharia/IME, Pça. Gen. Tiburcio, 80, Urca, Rio de Janeiro, R.J., Brazil \\ ${ }^{2}$ Centro Bras. de Pesq. Físicas/CBPF, R. Dr. Xavier Sigaud, 150, Urca, Rio de Janeiro, R.J., Brazil \\ aflavia@ime.eb.br, ${ }^{\mathrm{b}}$ louro@ime.eb.br, ${ }^{\mathrm{c} b r a n t @ c b p f . b r}$, ${ }^{\mathrm{d}}$ rossi@cbpf.br, ${ }^{\mathrm{e}}$ marceloprado@ime.eb.br
}

Keywords: gelcasting, $\alpha-\mathrm{TCP}, \beta-\mathrm{TCP}$, hydroxyapatite. bioceramics, polyethylene wax.

\begin{abstract}
In the present work, apatite powders were synthesized at $\mathrm{pH} 10, \mathrm{pH} 11$ and $\mathrm{pH} 12$ in order to give rise to biphasic and triphasic bioceramics after sintering. A modified gelcasting process, including polyethylene wax spheres addition to the suspension, is proposed in comparison to the original gelcasting method. The aim of the addition is the creation of uniform, open and interconnected pores in the body of samples.
\end{abstract}

\section{Introduction}

Gelcasting is a technique used to produce samples with complex shapes, and porous ceramics are included in this classification. The scaffolds prepared have open, uniform and interconnected pores. The necessity of interconnection is to allow cells and tissue ingrowth, vascularization, and diffusion of nutrients through the scaffold.

This process needs many reagents as monomers, dispersants, surfactants, iniciator and catalyst to develop a scaffold, including controlled atmosphere to give rise to a complete polymerization process. The main suggestion of this work is to compare the original gelcasting with a modification in this process including polyethylene wax addition [1]. Previous studies have been done in an attempt to produce alumina and hydroxyapatite porous bodies by gelcasting [2-4].

Upon sintering above $1250{ }^{\circ} \mathrm{C}$, samples with $\mathrm{Ca} / \mathrm{P}$ ratio ranging from 1.55 to 1.57 originated multiphasic bioceramics based on $\mathrm{Ca}_{10}\left(\mathrm{PO}_{4}\right)_{6}(\mathrm{OH})_{2}, \beta-\mathrm{Ca}_{3}\left(\mathrm{PO}_{4}\right)_{2}$ and $\alpha-\mathrm{Ca}_{3}\left(\mathrm{PO}_{4}\right)_{2}$ with different proportions, resulting in materials with low densities.

The compositions and experimental conditions were determined with the aim to optimize the biodegradation and structure parameters to produce bone fillers or tissue engineering scaffolds. The $\mathrm{Ca} / \mathrm{P}$ atomic ratio is a particularly relevant parameter because both crystallinity and bio-resorption rate depend on it. The powders with different $\mathrm{pH}$ were used in mixtures with and without polyethylene wax and were analyzed to see the difference between then.

\section{Materials and Methods:}

Synthesis of apatite powders were made at $\mathrm{pH} 10, \mathrm{pH} 11$ and $\mathrm{pH} 12$ in order to allow the production of precursors of different phases. The powders were synthesized in aqueous solution by slow addition of orthophosphoric acid to a calcium hydroxide suspension and lactic acid solution containing ammonium hydroxide to adjust the $\mathrm{pH}$ value to $\mathrm{pH} 10$ and $\mathrm{pH} 11$ and potassium hydroxide, a strong base, to adjust the value to $\mathrm{pH} 12$. The precipitate was aged for $24 \mathrm{~h}$ before filtering. The filtered cake was dried at $90^{\circ} \mathrm{C}$ and then ground to a powder. The method used was described elsewhere [5].

The solution vehicle was an aqueous solution containing $25 \%$ weight of monomers in a $6 / 1$ ratio and dispersant [6], as it was described in previous work [1]. This solution was added to $35 \%$ of the volume of hydroxyapatite and wax spheres, to give rise pores larger than $100 \mu \mathrm{m}$, and after sonicated during 20 minutes. The slurry was placed into moulds in a glove box with a nitrogen 
controlled atmosphere. The foams were produced in a controlled atmosphere to avoid oxygen contamination which could inhibit the monomers polymerization process [7].

The suspension was separated and added to surfactant and catalyst, and soon after mixed by during 3 minutes, producing the foam. Then the initiator was dropped to the slurry to promote polymerization. The surfactant genaminox $\mathrm{KC}$ (cocoalkyldimethylamineoxide, Clariant, Brazil) generates very high foam volumes even at very low concentrations, and its presence is necessary to stabilize the liquid-gas interface of bubbles in suspensions, retaining the foam. The foamed slurry was poured into molds and placed overnight in the glove box. Some samples were also made with the same amount but without polyethylene wax spheres, the original gelcasting technique [8], in order to observe the pores interconnections and to compare the modification.

The green bodies were air dried during 24 hours, then at $90^{\circ} \mathrm{C}$ during 24 hours and sintered at $1250^{\circ} \mathrm{C}$ with controlled heating rate to eliminate the organic additives without collapsing the struts. The heating schedule used was $0.5^{\circ} \mathrm{C} / \mathrm{min}$ up to $550^{\circ} \mathrm{C}$, keeping 2 hours at $550^{\circ} \mathrm{C}, 5^{\circ} \mathrm{C} / \mathrm{min}$ from $550^{\circ} \mathrm{C}$ to $1250{ }^{\circ} \mathrm{C}$ and $1 \mathrm{~h}$ at the sintering temperature, $1250^{\circ} \mathrm{C}$. After sintering, morphology pores distributions and phases proportions of the samples were determined.

$\mathrm{Ca} / \mathrm{P}$ ratio was determined by X-ray fluorescence spectroscopy using a Philips PW 2400 equipment. Phase characterization was performed using XRD (X-Ray Diffraction) techniques. XRD measurements were performed on these samples using a Panalytical X PERT PRO difractometer with $\mathrm{CuK} \alpha$ radiation, a scanning step of $0.05^{\circ}$ and a collecting time of 8 seconds per step. Quantitative Rietveld calculations were performed using TOPAS Academic, which includes First Principals (FP) calculations for phase determination. Fourier transform-infrared spectroscopy (FT-IR Prestige - 21/ Shimadsu) analyses were used to assess the present functional groups on the as-precipitated powders as well as on sintered samples.

Scanning electron microscopy analyses of the struts were performed in a Jeol JSM - 5800 LV scanning electron microscope.

\section{Results and Discussion:}

The precursor apatite powders synthesized in this study showed to be unstable under sintering, giving rise to biphasic HA/ $\beta$-TCP or triphasic HA/ $\beta-\mathrm{TCP} / \alpha-\mathrm{TCP}$ mixture, depending on the $\mathrm{pH}$ and the sintering temperature. The results of $\mathrm{X}$-ray diffraction characterization of the produced samples showed the presence of: $\mathrm{HA}$ and $\beta$-TCP at $\mathrm{pH} 10$ sintered at $1100^{\circ} \mathrm{C} ; \alpha$ and $\beta-\mathrm{TCP}$ and hydroxyapatite at $\mathrm{pH} 12$ at $1100^{\circ} \mathrm{C}$ and $1250^{\circ} \mathrm{C}$. The results were also refined and from the Rietveld calculations, it is evident that $\alpha$-TCP content increases with increasing sintering temperature and $\mathrm{HA}$ content increases with increasing $\mathrm{pH}$ during synthesis. Apatite powders synthesized at low $\mathrm{pH}$ values, presented high $\beta$-TCP content, which decomposed into $\alpha$-TCP under temperatures of $1250^{\circ} \mathrm{C}$. The high tricalcium phosphate content in the studied samples agrees with the XRF analysis that showed $\mathrm{Ca} / \mathrm{P}$ ratio for the sintered samples ranging from 1.55 to 1.57 .

The XRD Quantitative measurements were performed using TOPAS Academic program for Rietveld analysis. Rietveld refinement result confirmed the trend of increasing HA content with increasing $\mathrm{pH}$ during synthesis and more of $\alpha$ - TCP with increasing sintering temperature. All samples presented $\beta$ - TCP. At $\mathrm{pH} 10$, HA and $\beta$-TCP were present; at $\mathrm{pH} 10$ at $1250^{\circ} \mathrm{C}, \beta-\mathrm{TCP}$ decomposed to $\alpha$-TCP and HA decomposed to $\beta$-TCP. Samples synthesised at $\mathrm{pH} 12$ showed the presence of HA and $\beta$-TCP after sintering at $1100^{\circ} \mathrm{C}$. However, at $1250^{\circ} \mathrm{C}$, decomposition appeared giving rise to a triphasic composition: HA, $\beta$-TCP and $\alpha$-TCP as shown in Fig 1 


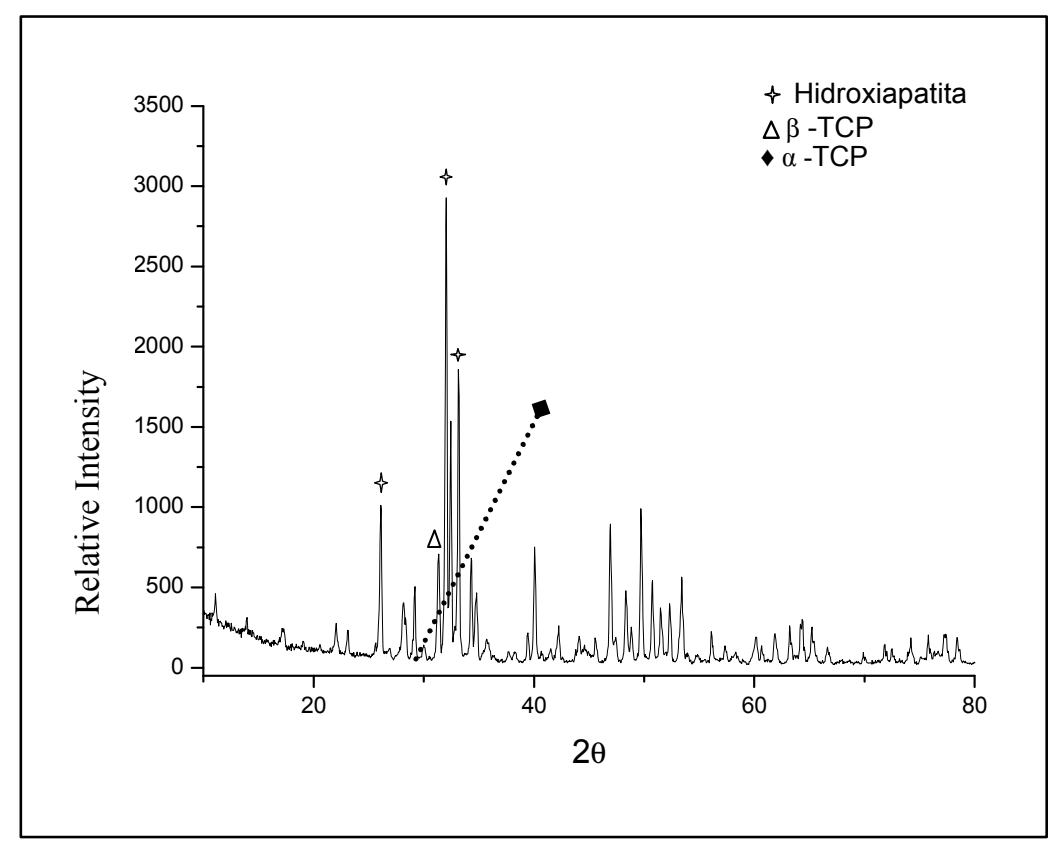

Figure 1. XRD result of $\mathrm{pH} 12$ sample with the presence of $\alpha$-TCP, $\beta$-TCP and hydroxyapatite at $1250^{\circ} \mathrm{C}$.

Scanning electron microscopy analyses on the prepared scaffolds without polyethylene wax spheres showed open and interconnected pores. The surfactant was essential to create the interconnections. Fig. 2 shows the morphology of the samples produced without polyethylene wax spheres. The micrographs clearly demonstrate the presence of macropores and micropores with varying sizes without an uniformity. The micrographs in Fig.3, clearly demonstrate that wax spheres addition created uniform macro porosity, with micropores due to surfactant and macropores with diameters above $100 \mu \mathrm{m}$, which are suitable for cells migration, spread and proliferate.

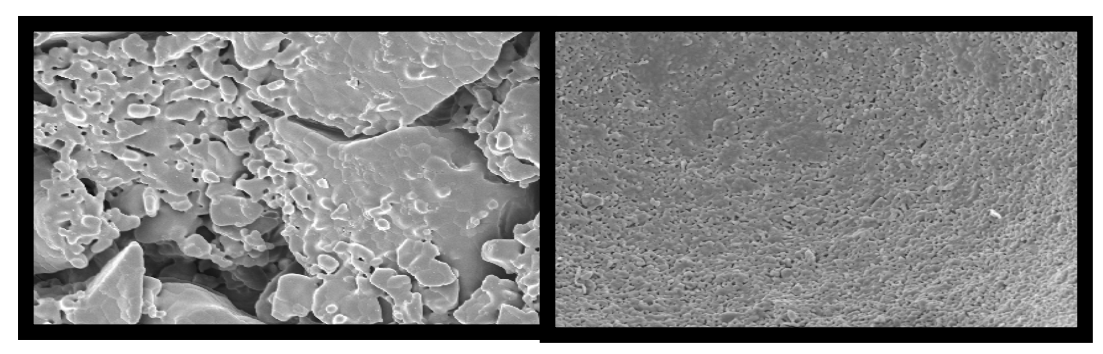

(a)

(b)

Figure 2. SEM analysis on samples produced at $\mathrm{pH} 10$ (a) and $\mathrm{pH} 12$ (b) without polyethylene wax spheres. Magnification $=500 \mathrm{X}$.

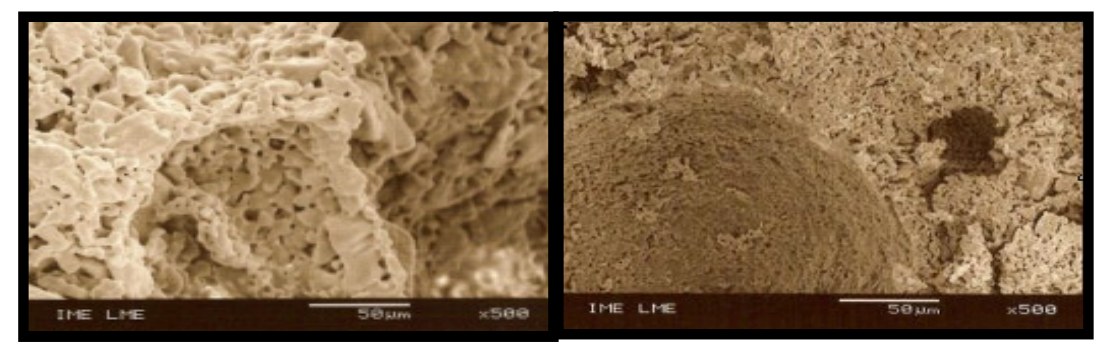

(a)

(b)

Figure 3. SEM analysis on samples produced at $\mathrm{pH} 10$ (a) and $\mathrm{pH} 12$ (b) with polyethylene wax spheres. Magnification $=500 \mathrm{X}$. 
Both types of processing routes produced total porosity levels of up to $65 \%$. However, conventional gelcasting specimens exhibited a high percentage of open porosity with pore diameters and interconnections below $100 \mu \mathrm{m}$, while the process with spheres exhibited more interconnected porosity with pore channels with diameters above $100 \mu \mathrm{m}$.

\section{Conclusions:}

Hydroxyapatite and TCP scaffolds with different phases proportions were produced and developed by a modification of the gelcasting process. The phases percentage control enables the design of a multiphasic bioceramic with bioresorption rates similar to those of newly bone formation. The benefits of modified gelcasting remain in the ability to design complex geometries with the ability to control the size and level of porosity (open and interconnected porosity).

The technique showed to be efficient in producing porous biphasic and triphasic bodies, by simple control of $\mathrm{pH}$ and sintering temperature. The porous bodies have good potential to be used as bone substitutes and as tissue engineering scaffolds. The samples made with surfactant and wax spheres showed more interconnections and uniform pores, when compared to samples produced without wax spheres.

\section{References}

[1] F.Mendonça, L.H.Louro, J.B.de Campos, M.H.Prado da Silva, Key Eng Mater, V.361-363 (2008)p.2730.

[2] R. Ramay, M. Zang, Biomaterials 24 (2003) 3293- 3302.

[3] P. Sepulveda, J. G. P. Binner (1999), J. Eur. Ceram. Soc., v. 19, p. 2059-2066.

[4] F. S Ortega, P. A. S. Inostroza, V. C. Pandolfelli (2000), Cerâmica, v.46, n.300, p.225-229.

[5] S. V. Albuquerque, R. E. F. Nogueira, T. D. Pinheiro da Silva, D. O. Lima, M. H. Prado da Silva (2004), Key Eng. Mater., v. 254-256, p.1021-1024

[6] C. Young, O. Omatete, M. A. Janney, P. A. Menchhofer (1991), J.Am. Ceram. Soc., v.74, p. 3612- 3618.

[7]. S. Padilla, M. Vallet-Regí, M. P. Ginebra , F. J. Gil, Journal of the European Ceramic Society (2005) v. 25 , p. $375-383$

[8]. M. A. Janney, S. D. Nunn, C. A. Walls,O. O. Omatete, R. B. Ogle, G. H. Kirby, and A. D. McMillan THE HANDBOOK OF CERAMIC ENGINEERING(1998), Mohamed N. Rahaman, Editor, Marcel Dekker 